\title{
Bisdemethoxycurcumin Suppresses Migration and Invasion of Human Cervical Cancer HeLa Cells via Inhibition of NF-kB, MMP-2 and -9 Pathways
}

\author{
CHING-LUNG LIAO ${ }^{*}$, YUNG LIN CHU ${ }^{2 *}$, HUI-YI LIN ${ }^{3}$, CHENG-YEN CHEN $^{4}$, MING-JIE HSU ${ }^{4}$, \\ KUO-CHING LIU ${ }^{5}$, KUANG-CHI LAI ${ }^{6,7}$, AN-CHENG HUANG $^{8 \#}$ and JING-GUNG CHUNG ${ }^{4,9 \#}$ \\ ${ }^{1}$ College of Chinese Medicine, School of Post-Baccalaureate Chinese Medicine, \\ ${ }^{3}$ School of Pharmacy, and Departments of ${ }^{4}$ Biological Science and Technology, and \\ ${ }^{5}$ Medical Laboratory Science and Biotechnology, China Medical University, Taichung, Taiwan, R.O.C.; \\ ${ }^{2}$ International Master's Degree Program in Food Science, International College, \\ National Pingtung University of Science and Technology, Pingtung, Taiwan, R.O.C.; \\ ${ }^{6}$ Department of Medical Laboratory Science and Biotechnology, College of Medicine and Life Science, \\ Chung Hwa University of Medical Technology, Tainan, Taiwan, R.O.C.; \\ ${ }^{7}$ Department of Surgery, China Medical University Beigang Hospital, Beigang, Taiwan, R.O.C.; \\ ${ }^{8}$ Department of Nursing, St. Mary's Junior College of Medicine, Nursing and Management, Yilan, Taiwan, R.O.C.; \\ ${ }^{9}$ Department of Biotechnology, Asia University, Taichung, Taiwan, R.O.C.
}

\begin{abstract}
Background/Aim: Bisdemethoxycurcumin (BDMC) exhibits biological activities including anticancer and antimetastasis in human cancer cell lines, but there is no available information to show whether BDMC suppresses cell migration and invasion of human cervical cancer cells. Materials and Methods: Wound-healing, migration, invasion, zymography, and western blotting assays were used to investigate the effects of BDMC on HeLa cells in vitro. Results: BDMC reduced the total viable cell number in a dose-dependent manner. The wound-healing assay show BDMC suppressed the movement of HeLa cells. Furthermore, the trans-well chamber assays showed that BDMC suppressed the cell migration and invasion. Gelatin zymograph assay showed that BDMC did not inhibit matrix metalloproteinase-2 (MMP-2) and -9 activities in vitro. However, western blotting assay showed that
\end{abstract}

\footnotetext{
*,\#These Authors contributed equally to this study.

Correspondence to: Professor Jing-Gung Chung, Department of Biological Science and Technology, China Medical University, No 91, Hsueh-Shih Road, Taichung, Taiwan. Tel: +886 422053366, ext. 8000, Fax: +886 422053764, e-mail: jgchung@mail.cmu.edu.tw; AnCheng Huang, Ph.D., Department of Nursing, St. Mary's Junior College of Medicine, Nursing and Management, No 100, Ln 265, Sec 2, Sanxing Road, Sanxing Township, Yilan County, Taiwan. Tel: +88639897396 ext. 503, e-mail: haj@smc.edu.tw
}

Key Words: Bisdemethoxycurcumin, BDMC, migration, invasion, NF-kB p65, HeLa human cervical cancer cells.
BDMC significantly reduced protein levels of growth factor receptor-bound protein 2 (GRB2), Ras homolog gene family, member A (Rho A), urokinase-type plasminogen activator (uPA), RAS, MMP-2, and N-cadherin but increased those of phosphor-extracellular-signal related kinase (p-ERK1/2), E-cadherin and nuclear factor- $k B(N F-k B)$ in HeLa cells. Confocal laser microscopy assay was used to further confirm BDMC increased NF-kB when compared to controls. Conclusion: BDMC may have potential as a novel antimetastasis agent for the treatment of human cervical cancer.

Uterine cervical cancer is the fourth most common cancer in women (1). In Taiwan, cervical cancer is the eighth most common cancer among females, the animal report by the Department of Health, Taiwan, R.O.C. for 2016 indicated that 54 individuals per 1,000,000 died annually from cervical cancer (2). Compared to other cancer types, screening for cervical cancer is the most effective (3). Currently, surgery, chemotherapy and radiotherapy or their combination are used for clinical patients with cervical cancer but side-effects, resistance and recurrence still occur (4). In particular, approximately $90 \%$ of patients with cancer die due to the result of invasive and metastatic growth of cancer $(5,6)$. Therefore, in order to improve clinical outcomes in cervical cancer, new chemotherapeutics directed towards inhibiting cancer cell metastasis are urgently needed.

The essential features of the metastatic process include tumor cell invasion and migration $(7,8)$. Matrix metalloproteinases (MMPs) degrade mechanical barrier such as extracellular matrix 
and basement membrane leading to cell movement (9). It is well documented that the proteolytic activities of MMPs are involved in the metastasis process, including enabling cell adhesion, migration, and invasion $(10,11)$. MMP-2 (gelatinase) plays an important role in degrading basement membranes and is involved in cancer invasion and metastasis (12-14); increased MMP-2 expression is associated with reduced survival and poor prognosis in human malignancies $(15,16)$. Increased mRNA and protein levels of MMP-2 have been detected in cervical cancer (17). Other studies have shown that MMP inhibitors used in patients with metastatic cancer may adequately treat metastasis $(18,19)$.

Turmeric, one of the most popular medicinal herbs in India and China, has a wide range of pharmacological activities, for treating ulcers, skin diseases and the symptoms of colds and flu (20) and to cure immune-related, metabolic diseases and cancer with no side-effects $(20,21)$. The major pharmacological activity of turmeric is attributed to curcuminoids that include curcumin and two related compounds demethoxy curcumin (DMC) and bisdemethoxycurcumin (BDMC) (22). BDMC induces mitochondrial dysfunction and apoptosis in PANC-1 human pancreatic cancer cells (23). In 95D non-small cell lung cancer cells, Hsieh et al. showed the effects of BDMC on transforming growth factor- $\beta 1$-induced epithelial-tomesenchymal transition (EMT) are mediated through Wnt inhibitory factor-1, revealing a novel mechanism of EMT regulation (24).

Although studies on BDMC exist, no reports show actual anti-metastatic effects on cancer cells. Therefore, in the present study, we analyzed the effects of BDMC on migration and invasion of HeLa human cervical cancer cells in vitro. In addition, we also investigated the role of MMP-2 and -9 and NF- $\mathrm{kB}$ signaling pathways in HeLa cells after exposure to BDMC.

\section{Materials and Methods}

Chemicals and reagents. BDMC, dimethyl sulfoxide (DMSO) and propidium iodide (PI) were purchased from Sigma-Aldrich (St. Louis, MO, USA). Dulbecco's modified Eagle's medium (DMEM), fetal bovine serum (FBS), L-glutamine, penicillin and streptomycin were purchased from GIBCO ${ }^{\circledR} /$ Invitrogen Life Technologies (Grand Island, NY, USA). Polyvinylidene difluoride membrane was obtained from Millipore (Temecula, CA, USA). The following primary antibodies were used: GRB2, RAS and NF-kB p65 all from BD Pharmingen (San Jose, CA, USA); ROHA, p-ERK1/2, ERK1/2, NF-kB p50 and uPA all from Santa-Cruz Biotechnology Inc. (Dallas, TX, USA); SNAIL and E-cadherin from Cell Signaling (St Louis, MO, USA). MMP-2, Ncadherin, $\beta$-catenin, vimentin, and $\beta$-actin from Sigma Chemical Co. (St. Louis, MO, USA); MMP-9 from Millipore (Temecula, CA, USA); and PCNA from GeneTex Inc. (Irvine, CA, USA).

Cell culture. HeLa human cervical cancer cell line was purchased from the Food Industry Research and Development Institute (Hsinchu, Taiwan, ROC). Cells were cultured in DMEM containing

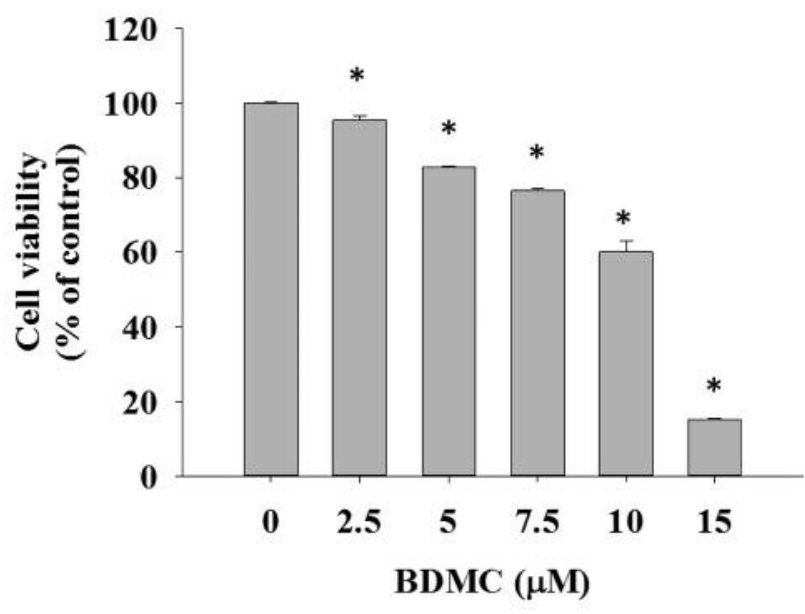

Figure 1. Bisdemethoxycurcumin (BDMC) reduced the viable cell number of HeLa cells. Cells were kept in 12-well plates with Dulbecco's modified Eagle's medium for $24 h$ and were incubated with BDMC at final concentrations of $0,2.5,5.0,7.5,10$ and $15 \mu M$, or $0.5 \%$ dimethylsulfoxide as a vehicle control for $48 \mathrm{~h}$. After incubation, cells were collected, counted and stained with propidium iodide $(5 \mu \mathrm{g} / \mathrm{ml})$ to measure the total viable cell number by flow cytometry as described in Materials and Methods. *Significantly different from the control at $p<0.05$.

$10 \% \mathrm{FBS}, 100$ units $/ \mathrm{ml}$ penicillin and $100 \mu \mathrm{g} / \mathrm{ml}$ streptomycin in a humid atmosphere incubator with $5 \% \mathrm{CO}_{2}$ at $37^{\circ} \mathrm{C}(24)$.

Cell viability assays. HeLa cells were seeded in 12-well plates at an initial density of $10^{5}$ cells per well with DMEM for $24 \mathrm{~h}$. They were then incubated with $\operatorname{BDMC}(0,2.5,5.0,7.5,10$ and $15 \mu \mathrm{M})$ or $0.5 \%$ DMSO as a vehicle control for $48 \mathrm{~h}$. After incubation, cells were collected, counted and stained with PI $(5 \mu \mathrm{g} / \mathrm{ml})$ to measure the total cell viability by flow cytometry (FACSCalibur; BD Biosciences, San Jose, CA, USA) as previously described (24).

Wound-healing assay. HeLa cells $\left(5 \times 10^{5}\right.$ cells/well $)$ were seeded in 6well plate and grown to about $90 \%$ confluence after $24 \mathrm{~h}$. The medium was removed and cell monolayers were wounded by manually scraping the cells with a $200 \mathrm{ml}$ plastic pipette tip, and were then washed with phosphate buffered saline (PBS) three times. Cells were then cultured in DMEM containing 0, or $5 \mu \mathrm{M}$ of BDMC for 24 and $48 \mathrm{~h}$. Cells were examined and photographed using an inverted microscope at different time points as described previously $(25,26)$.

Invasion and migration assay (Matrigel and invasion assay). The assessment of in vitro invasion and migration activities were carried out using Matrigel-coated transwell cell culture chambers $(8 \mu \mathrm{m}$ pore size) as described previously (25). Briefly, HeLa cells $\left(5 \times 10^{5}\right.$ cells/well) in serum-free medium were maintained in 12-well plates and were incubated with 0 or $5 \mu \mathrm{M}$ of BDMC for 24 and $48 \mathrm{~h}$. For migration assay, cells were placed on the top of the well with membrane coated with collagen and then incubated with BDMC. The cells on the upper surface of the membrane were removed by a cotton swab and invaded cells on the lower surface were fixed with $4 \%$ cold formaldehyde, stained with $0.1 \%$ crystal violet and then were photographed. The invading cells in the chamber were 

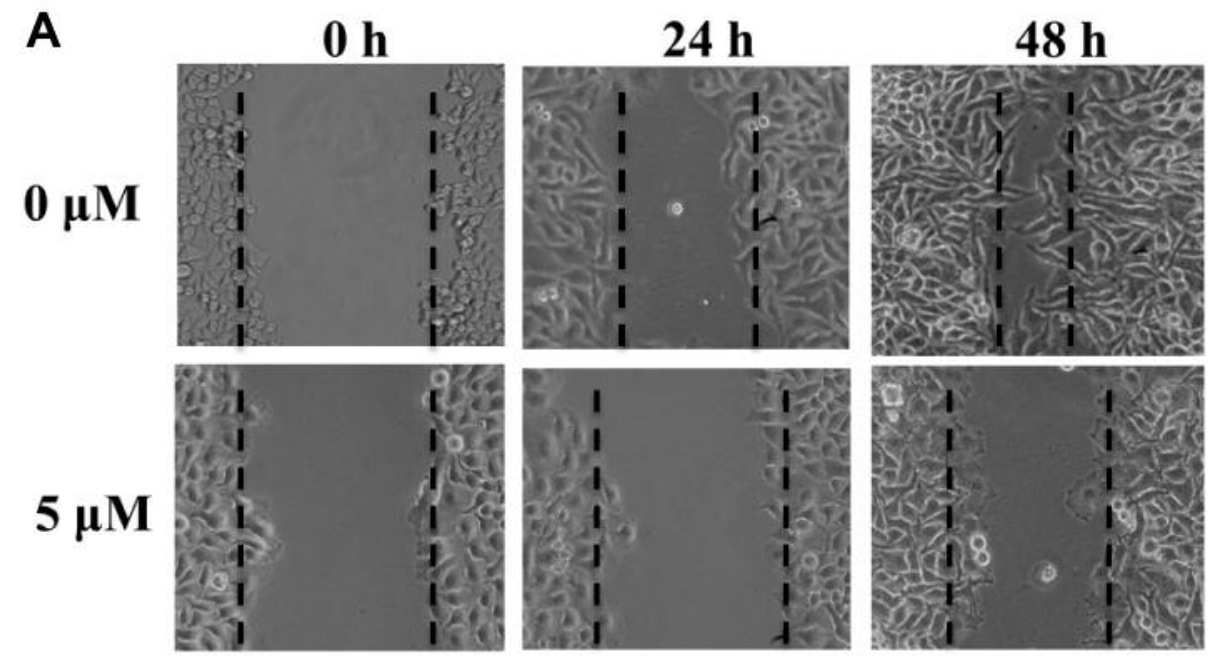

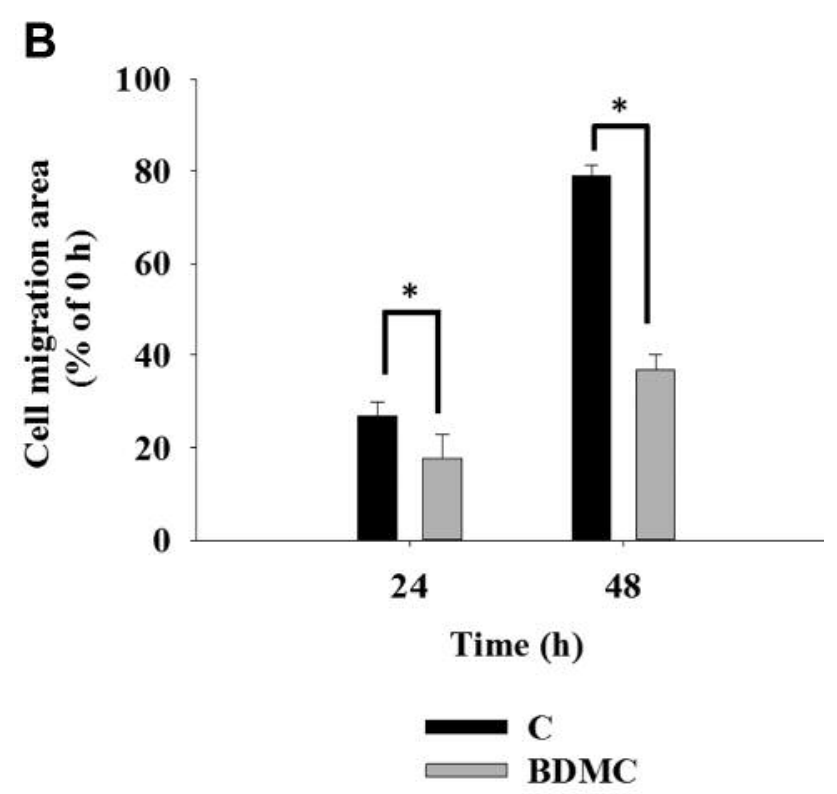

counted under a light microscope at a magnification of $\times 200$. For invasion assay, the same assay was used except the membrane was coated with matrigel as described previously $(25,27,28)$.

Gelatin zymography assay. HeLa cells were treated with $5 \mu \mathrm{M}$ of $\mathrm{BDMC}$ at $37^{\circ} \mathrm{C}$ for 12,24 and $48 \mathrm{~h}$ and the release of MMP-2 and MMP-9 was assayed using gelatin zymography (8\% zymogram gelatin gels) as described previously (25). Briefly, after incubation, the conditioned medium was collected, the total proteins measured were separated by $0.2 \%$ gelatin- $8 \%$ sodium dodecyl sulfate polyacrylamide gel electrophoresis (SDS-PAGE) ( $80 \mathrm{~V}$ for $120 \mathrm{~min})$. Afterwards, the gels were washed twice in a wash solution containing $2.5 \%(\mathrm{v} / \mathrm{v})$ Triton $\mathrm{X}-100$ at room temperature and subsequently incubated in substrate buffer $(50 \mathrm{mM}$ Tris $\mathrm{HCl}, 5 \mathrm{mM}$ $\mathrm{CaCl}_{2}, 0.02 \% \mathrm{NaN}_{3}$ and $1 \%$ Triton $\mathrm{X}-100, \mathrm{pH}$ 8.0) while shaking for $18 \mathrm{~h}$ at $37^{\circ} \mathrm{C}$. The gels were rinsed with distilled water and
Figure 2. Bisdemethoxycurcumin (BDMC) inhibited cell mobility of HeLa cells. Cells were grown in 6-well plates, then the cell monolayers formed were scraped and cells were then incubated in medium containing $O$ (control, $C$ ) and $5 \mu M$ of BDMC for 24 and $48 \mathrm{~h}$. After incubation, cells were examined and photographed, as described in the Materials and Methods. A: Representative images of closure of scrape area in the wounding assay. $B$ : The percentage of migration relative to the control is shown. *Significantly different from the control at $p<0.05$.

stained for 30 min with $0.2 \%$ Coomassie blue (Bio-Rad, Hercules, CA, USA) in $10 \%$ acetic acid and $50 \%$ methanol and were photographed on a light box. The gelatinolytic activities of MMP-2 and -9 were densitometrically quantified and analyzed by an image analysis system (Bio-Rad Laboratories, Richmond, CA, USA) as described previously (25).

Western blotting assay. HeLa cells $\left(6 \times 10^{6}\right.$ cells $)$ were harvested after 0 and $5 \mu \mathrm{M}$ of BDMC treatment for 12, 24 and $48 \mathrm{~h}$. Cells were collected and lysed in a PRO-PREP protein extraction solution [40 mM Tris- $\mathrm{HCl}$ (pH 7.4), $10 \mathrm{mM}$ EDTA, $120 \mathrm{mM} \mathrm{NaCl}, 1 \mathrm{mM}$ dithiothreitol, $0.1 \%$ Nonide P-40] (iNTRON Biotechnology, FL, USA), and Bio-Rad Bradford protein assay (Bio-Rad, Hercules, CA, USA) was used for measuring the total protein (25). Thirty micrograms of protein was electrophoresed loaded on a SDS-PAGE gel and was transferred to a polyvinylidene difluoride membrane. 

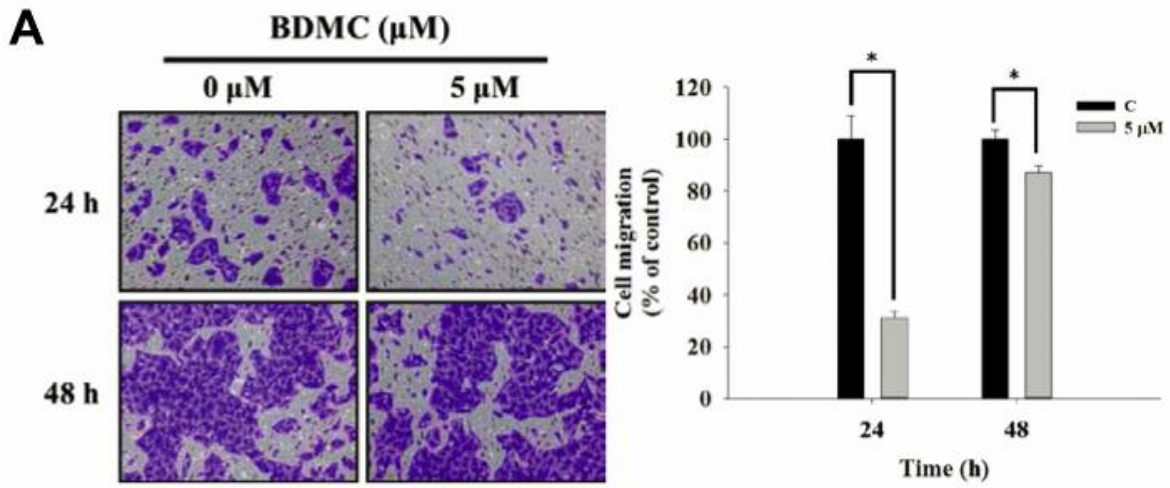

B
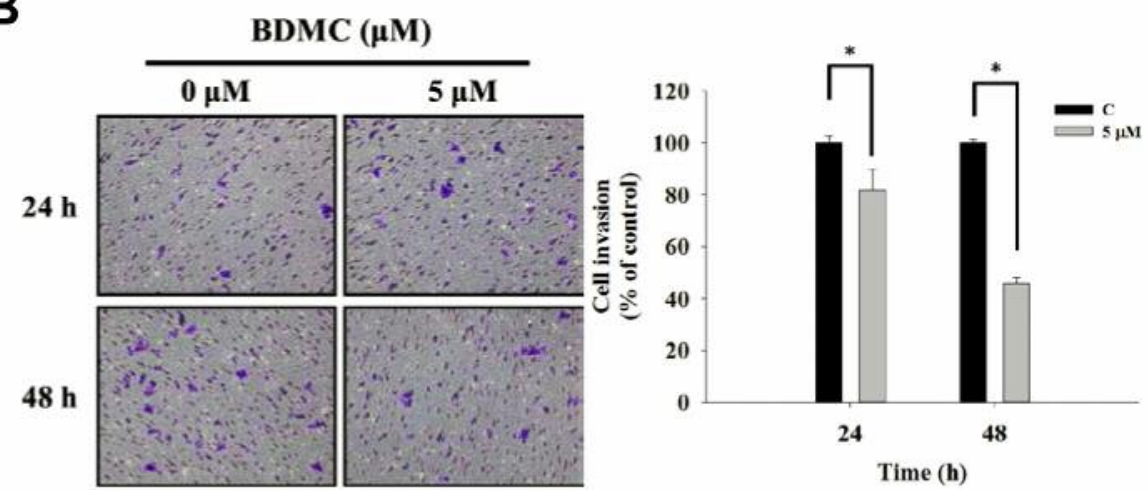

Figure 3. Bisdemethoxycurcumin (BDMC) inhibited the cell migration and invasion of HeLa cells. The measurement of cell migration (A) and invasion $(B)$ were performed by using Trans-well cell migration and invasion assays as described in the Materials and Methods. *Significantly different from the control $(C)$ at $p<0.05$.
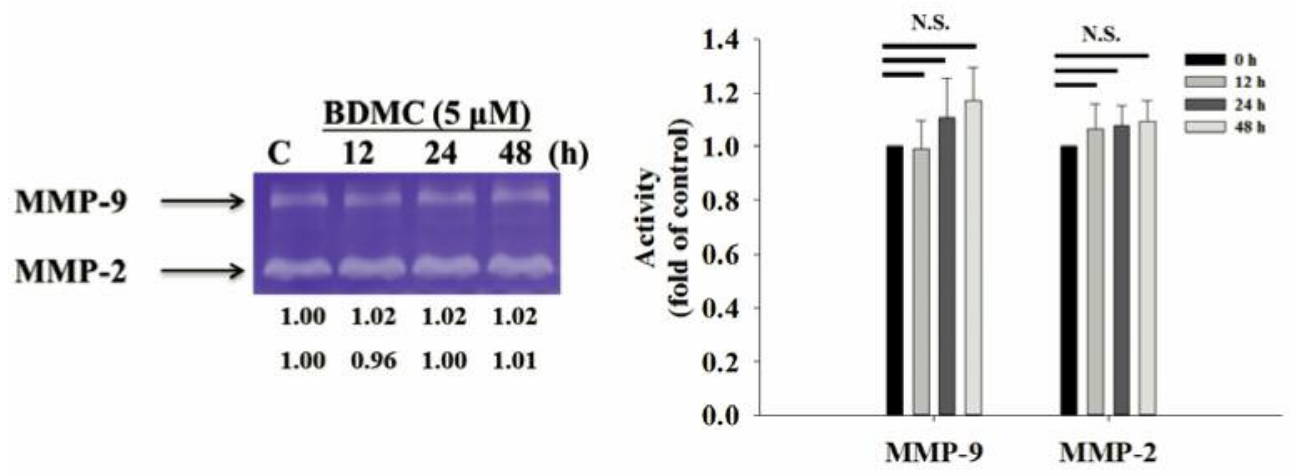

Figure 4. Bisdemethoxycurcumin (BDMC) did not inhibit the activity of matrix metalloproteinase-2 (MMP-2) and -9 in HeLa cells. HeLa cells were incubated with BDMC (5 $\mu M)$ for 12, 24 and $48 \mathrm{~h}$, and the gelatinolytic activity of MMP-2/-9 were measured as described in the Materials and Methods. N.S.: Not significantly different from the control (C).

The membrane was blocked in 5\% fat-free dry milk solution in PBS and probed with corresponding (diluted $1: 1,000$ ) overnight at $4^{\circ} \mathrm{C}$. After washing, anti-mouse or anti-rabbit IgG (diluted 1:10,000) was added to the membranes for $1 \mathrm{~h}$ at room temperature. The proteins were visualized using enhanced chemiluminescence reagents (Millipore, Temecula, CA, USA). The signal was detected using a gel documentation system (Molecular Imager ChemiDoc ${ }^{\mathrm{TM}}$ XRS+
Imaging System; Bio-Rad, Hercules, CA, USA) as described previously $(25,29)$.

Confocal laser microscopy assay. Results from western blotting demonstrated that BDMC affect NF- $\mathrm{kB}$ protein expression in HeLa cells, thus, for further confirming whether or not BDMC inhibition of cell migration and invasion were involved in the translocation or 

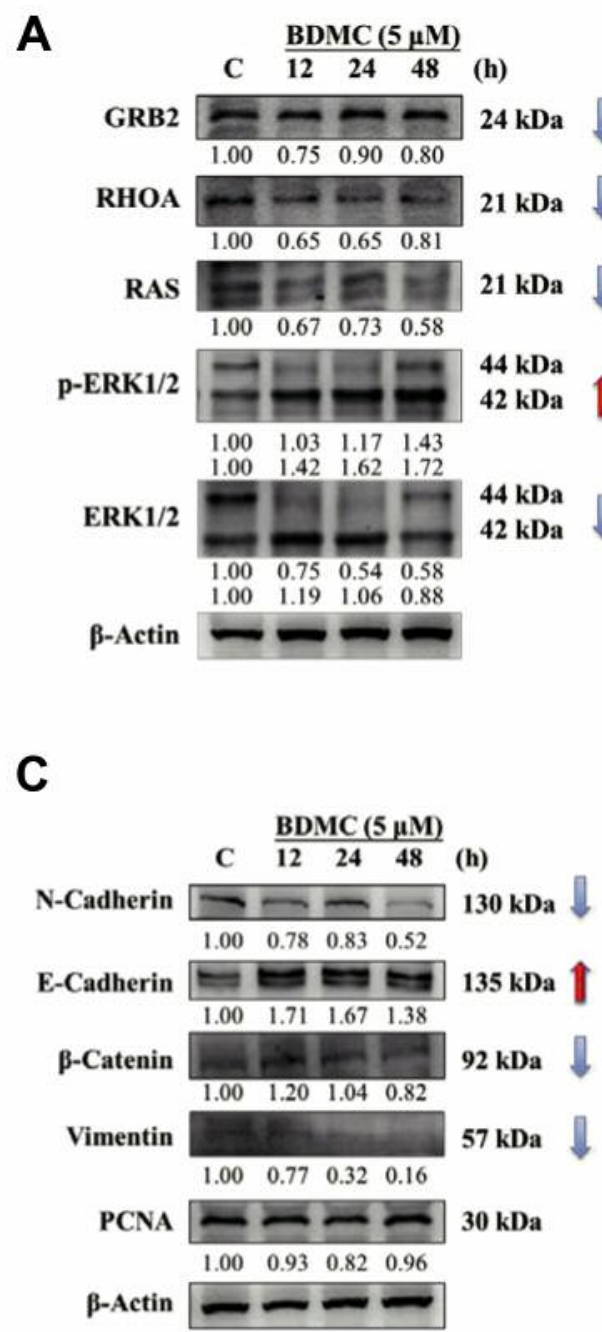

expression of NF-kB, HeLa cells were treated with $5 \mu \mathrm{M}$ of BDMC for $24 \mathrm{~h}$ and were examined and photographed by confocal laser microscopy systems as described previously (30).

Statistical analysis. All data are expressed as means \pm SD from at least three experiments. Differences between groups were analyzed by one-way analysis of variance and Dunnett test for multiple comparisons (SigmaPlot for Windows version 12.0; Systat Software, Inc., San Jose, CA, USA). Comparisons were made between groups of BDMC-treated cells and untreated cells (control). Differences with values of $p<0.05$ were considered statistically significant.

\section{Results}

$B D M C$ reduces cell viability of HeLa cells. Data shown in Figure 1 indicate a significant dose-dependent reduction of living HeLa cells after incubated with BDMC for $48 \mathrm{~h}$; therefore, the $20 \%$ inhibitory concentration $\left(\mathrm{IC}_{20}\right)$ of $5 \mu \mathrm{M}$ was used for cell migration and invasion experiments.

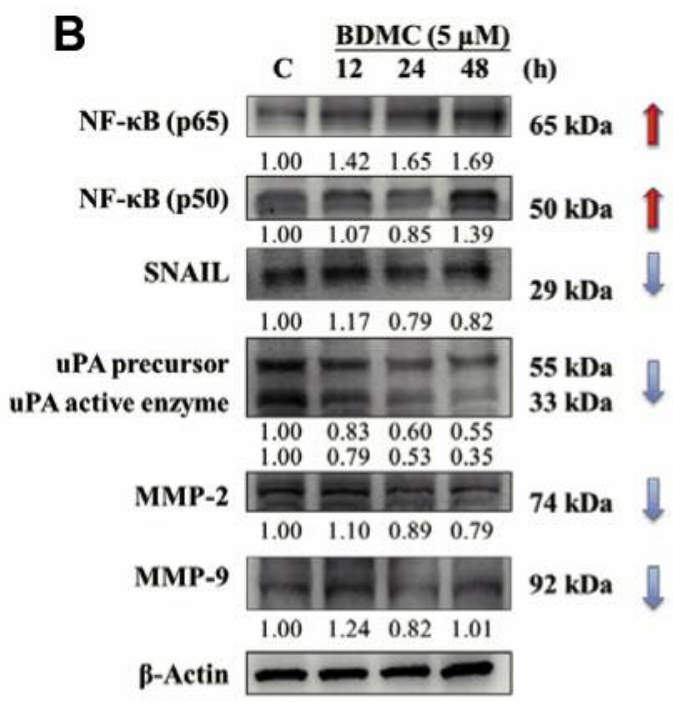

Figure 5. Bisdemethoxycurcumin (BDMC) altered the levels of proteins associated with migration and invasion of HeLa cells. Cells were treated with $5 \mu M$ of BDMC for 12,24 and $48 \mathrm{~h}$ and then total proteins were quantitated and metastasis associated proteins were examined by western blotting as described in the Materials and Methods. A: Growth factor receptor-bound protein 2 (GRB2), Ras homolog gene family, member A (RHOA), RAS, phosphor-extracellular-signal related kinase $(p-E R K 1 / 2)$ and extracellular-signal related kinase (ERK1/2). $B$ : nuclear factor kappa $B(N F-k B) p 65$ and p50, zinc-finger transcription factor snail (SNAIL), urokinase-type plasminogen activator (uPA), matrix metalloproteinase-2 (MMP-2) and -9. C: $N$-Cadherin, E-cadherin, $\beta$-catenin, vimentin and proliferating cell nuclear antigen (PCNA). Arrows indicate the effect of BDMC.

BDMC reduces mobility of HeLa cells. The results of the wound-healing essay indicate that the closure of the wound for BDMC-treated cells was less than that of the control for both treatment durations (Figure 2A). BDMC significantly inhibited cell mobility at $5 \mu \mathrm{M}$ in 24 and $48 \mathrm{~h}$ compared with the control (Figure 2B).

BDMC inhibites migration and invasion of HeLa cells. Transwell cell migration and invasion assays were used for measuring cell migration and invasion in HeLa cells after exposure to BDMC. The results indicated that BDMC significantly $(p<0.05)$ inhibited cell migration by $31.24 \%$ and $87.07 \%$ at 24 and $48 \mathrm{~h}$ treatment, respectively (Figure $3 \mathrm{~A}$ ) and inhibited cell invasion by $81.55 \%$ and $45.76 \%$ at 24 and $48 \mathrm{~h}$ treatment, respectively, compared to control cells (Figure 3B). Based on these observations, BDMC significantly inhibited migration and invasion of HeLa cells. 


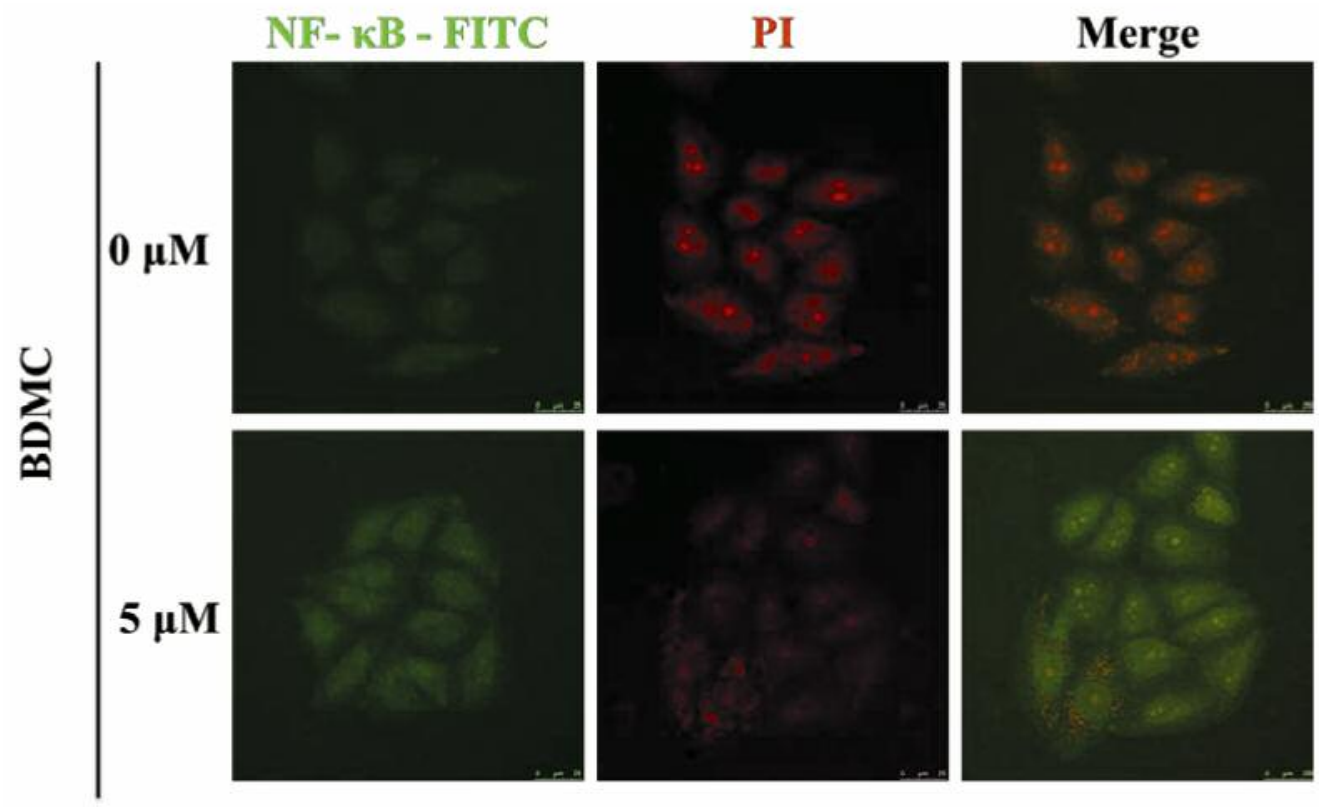

Figure 6. Bisdemethoxycurcumin (BDMC) affected the translocation of metastasis-associated proteins in HeLa cells. Cells were treated with $5 \mu$ M $B D M C$ for 24 h and cells were stained by anti-nuclear factor kappa B $(N F-k B)(p 65)$ and then were stained with secondary antibody [fluorescein isothiocyanate (FITC)-conjugated goat anti-mouse IgG (green fluorescence)] and were examined and photographed using a Leica TCS SP2 confocal laser microscopic systems as described in the Materials and Methods. PI: Propidium iodide.

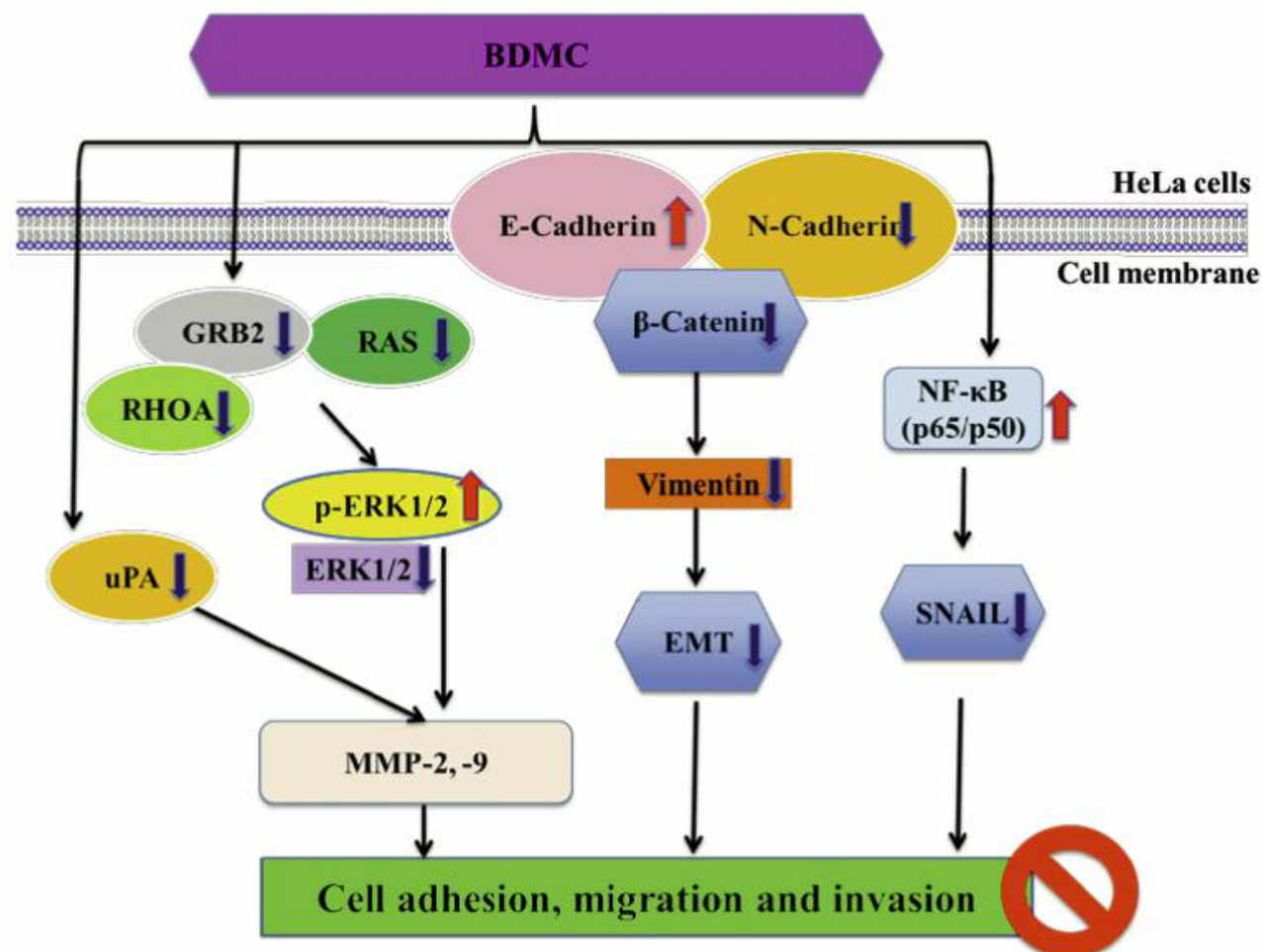

Figure 7. The possible signaling pathways for bisdemethoxycurcumin (BDMC) inhibition of cell migration and invasion of HeLa human cervical cancer cells. GRB2: Growth factor receptor-bound protein 2; RHOA: Ras homolog gene family, member A; p-ERK1/2: phosphor-extracellularsignal related kinase; ERK1/2: extracellular-signal related kinase; $N F-\kappa B$ : nuclear factor kappa B; SNAIL: zinc-finger transcription factor snail; uPA: urokinase-type plasminogen activator; MMP-2: matrix metalloproteinase-2; MMP-9: matrix metalloproteinase-9; PCNA: proliferating cell nuclear antigen; EMT: epithelial-mesenchymal transition. 
BDMC regulates the activities of MMP-2 and -9 in $\mathrm{HeLa}$ cells. Gelatin zymography for the gelatinolytic activity of MMP-2 and -9 indicated that BDMC did not significantly affect the gelatinolytic activity of MMP-2 or -9 when compared to the control groups (Figure 4).

BDMC alters levels of proteins associated with migration and invasion of HeLa cells. In order to explore the link between upstream regulated proteins associated with cell migration and invasion, after exposure to BDMC at $5 \mu \mathrm{M}$, HeLa cells were collected for western blotting and the results are presented in Figure 5. BDMC did not significantly affected PCNA, however, it significantly reduced the levels of GRB2, MMP2, MMP-9, ERK1/2, RAS, RHOA, SNAIL, N-cadherin, vimentin, $\beta$-catenin and uPA but increased those of $\mathrm{p}$-ERK1/2, E-cadherin and NF-kB (p65/p50) in HeLa cells in vitro.

BDMC alters the translocation of migration- and invasionassociated proteins in HeLa cells. In order to further confirm whether BDMC affects the translocation of NF- $\mathrm{kB}$, which was involved in cell migration and invasion of HeLa cells, cells were treated with or without $5 \mu \mathrm{M}$ of BDMC for $24 \mathrm{~h}$, and were stained with anti-NF-kB and then were examined and photographed by confocal laser microscopy system. The results in Figure 6 show that BDMC increased NF-kB expression in the cytoplasm and nucleus compared to the control $(0 \mu \mathrm{M})$ and the results were consistent with that of western blotting.

\section{Discussion}

Cancer cell metastasis involves a series of complicated processes including cell movement, adhesion, migration, invasion and angiogenesis to form new tumors in other sites of the body $(8,31)$. It is well known that during tumor progression, tumor cells acquire the expression of mesenchymal markers (vimentin, $\mathrm{N}$-cadherin, and fibronectin) but lose that of epithelial markers (E-cadherin) through EMT, enabling tumor metastasis (32). The molecular mechanisms underlying cancer invasion and metastasis are still not completely clear (33). Many studies have investigated natural products for inhibiting cancer cell metastasis. In India and China, the curcuminoids are commonly used as coloring agent as well as food additives. The World Health Organization stated the acceptable daily intake of curcuminoids to be in the range of $0-3 \mathrm{mg} / \mathrm{kg}$ as a food additive (34). Other studies have shown that curcuminoids inhibit cancer cell migration and invasion (35-38). BDMC, which is a curcuminoid, was shown to reduce cancer cell numbers through induction of cell-cycle arrest and apoptosis in human cancer cell lines $(23,24)$, however, its effects on cell migration and invasion of human cervical cancer cells have not been reported to our knowledge. Herein, we investigated the effects of BDMC on the HeLa cell migration and invasion in vitro.
The wound-healing assay protocol is acceptable for examining cancer cell mobility $(39,40)$. Results from Figures 2 indicated that BDMC significantly inhibited cell mobility of HeLa cells in vitro. Transwell-assay methods have been recognized as measuring the inhibition of cancer cell migration and invasion $(25,41)$. Herein, the Transwellassay was used to investigate HeLa cell migration and invasion after treatment with BDMC $(5 \mu \mathrm{M})$ for 24 and 48 $\mathrm{h}$ and results indicated that BDMC suppressed cell migration and invasion in vitro (Figure 3A). Based on these observations, we further investigated the molecular effects of BDMC inhibited cell migration and invasion of HeLa cells and possible alterations in the expression of several molecules. At first, we examined the gelatinolytic activity of MMP-2 and -9 treatment with BDMC. MMP-2 and MMP-9 are the gelatinase for degradation of the extracellular matrix $(6,42)$ and are considered to be valid drug targets (43). It was reported that BDMC inhibits cancer cell invasion through the down-regulation of MMPs and uPA (38). Herein, we demonstrated that BDMC inhibited invasion and motility of HeLa cells but did not reduce the activity of MMP-2 and -9 in vitro (Figure 4).

In the present study, BDMC reduced protein expression of GRB2, MMP-2, MMP-9, RAS, RhoA, SNAIL, N-cadherin, vimentin, $\beta$-catenin, uPA and ERK1/2, but increased the $p$ ERK1/2, E-cadherin and NF-kB (p65/p50) (Figure 5) in HeLa cells examined by western blotting assay. GRB2 has been reported to be involved in cell proliferation and migration of various types of cancer cell (44). BDMC significantly inhibited ERK1/2 but increased p-ERK1/2 in Hela cells (Figure 5A). ERK1/2 have been shown to contribute to cancer cell proliferation, migration and metastasis in some cell lines $(45,46)$ and increased pERK1/2 activity promotes cancer cell proliferation and metastasis in various cancer cell lines (47-49). Our findings indicate that BDMC reduced MMP-2 and -9 activities and protein expression, which may be via ERK1/2 phosphorylation, and it also inhibited the vimentin pathway in HeLa cells. BDMC increased E-cadherin but decreased Ncadherin in HeLa cells. It is reported that during cancer cell metastatic process, polarization of epithelial cells converted into mesenchymal cells was characterized by the loss of Ecadherin-mediated cell-cell contacts, as well as the acquisition of increased migratory and invasive potential (5054). We found that BDMC significantly inhibited NF- $\mathrm{kB}$ expression (Figure 6). NF- $\mathrm{kB}$ is a transcription factor closely linked to cell survival, proliferation and metastasis (55) and the NF-KB pathway has been recognized to be a target to treat inflammation and cancer (56).

In conclusion, in the present study, we found that BDMC induced cytotoxic effects on HeLa cells, thus, we selected the dose of BDMC that did not kill cells for inhibiting cell migration and invasion in vitro. BDMC suppressed cell 
mobility, migration and invasion in of HeLa cells through inhibition of MMP-2 and -9 signaling pathway by mechanisms that are summarized in Figure 7. Thus, we suggest that BDMC may be a potential candidate for developing preventive agents against human cervical cancer metastasis.

\section{Conflicts of Interest}

The Authors declare that there are no conflicts of interest in regard to this study.

\section{Acknowledgements}

This work was supported by the grant SMH106010 from Saint Mary's Hospital Luodong (Yilan, Taiwan) to An-Cheng Huang. Experiments and data analysis were performed in part through the use of the Medical Research Core Facilities Center, Office of Research \& Development at China medical University, Taichung, Taiwan.

\section{References}

1 Siegel RL, Miller KD and Jemal A: Cancer statistics, 2018. CA Cancer J Clin 68: 7-30, 2018.

2 Ministry of Health and Welfare: 2016 Statistics of Causes of Death. Taiwan, 2017.

3 IARC Working Group on Cervical Cancer Screening and the UICC Project Group on the Evaluation of Screening Programmes for Cancer: Screening for cancer of the uterine cervix. IARC Sci Publ: 1-315, 1986

4 Alshatwi AA, Periasamy VS, Athinarayanan J and Elango R: Synergistic anticancer activity of dietary tea polyphenols and bleomycin hydrochloride in human cervical cancer cell: Caspase-dependent and independent apoptotic pathways. Chem Biol Interact 247: 1-10, 2016.

5 Christofori G: New signals from the invasive front. Nature 441: 444-450, 2006.

6 Liu Z, Li L, Yang Z, Luo W, Li X, Yang H, Yao K, Wu B and Fang $\mathrm{W}$ : Increased expression of MMP9 is correlated with poor prognosis of nasopharyngeal carcinoma. BMC cancer 10: 270, 2010.

7 Friedl $\mathrm{P}$ and Wolf K: Tumour-cell invasion and migration: diversity and escape mechanisms. Nat Rev Cancer 3: 362-374, 2003.

8 Gupta GP and Massague J: Cancer metastasis: building a framework. Cell 127: 679-695, 2006.

9 Kumar A, El-Osta A, Hussain AA and Marshall J: Increased sequestration of matrix metalloproteinases in ageing human Bruch's membrane: implications for ECM turnover. Invest Ophthalmol Vis Sci 51: 2664-2670, 2010.

10 Folgueras AR, Pendas AM, Sanchez LM and Lopez-Otin C: Matrix metalloproteinases in cancer: from new functions to improved inhibition strategies. Int J Dev Biol 48: 411-424, 2004.

11 Kessenbrock K, Plaks V and Werb Z: Matrix metalloproteinases: regulators of the tumor microenvironment. Cell 141: 52-67, 2010.

12 Chang WL, Yu CC, Chen CS and Guh JH: Tubulin-binding agents down-regulate matrix metalloproteinase-2 and -9 in human hormone-refractory prostate cancer cells - a critical role of CDK1 in mitotic entry. Biochem Pharmacol 94: 12-21, 2015.

$13 \mathrm{Kim}$ JH, Kim JH, Kim SC, Yi YS, Yang WS, Yang Y, Kim HG, Lee JY, Kim KH, Yoo BC, Hong S and Cho JY: Adenosine dialdehyde suppresses MMP-9-mediated invasion of cancer cells by blocking the RAS/RAF-1/ERK/AP-1 signaling pathway. Biochem Pharmacol 86: 1285-1300, 2013.

14 Osman B, Akool el S, Doller A, Muller R, Pfeilschifter J and Eberhardt W: Differential modulation of the cytokine-induced MMP-9/TIMP-1 protease-antiprotease system by the mTOR inhibitor rapamycin. Biochem Pharmacol 81: 134-143, 2011.

15 Kallakury BV, Karikehalli S, Haholu A, Sheehan CE, Azumi N and Ross JS: Increased expression of matrix metalloproteinases 2 and 9 and tissue inhibitors of metalloproteinases 1 and 2 correlate with poor prognostic variables in renal cell carcinoma. Clin Cancer Res 7: 3113-3119, 2001.

16 Yoshizaki T, Maruyama Y, Sato H and Furukawa M: Expression of tissue inhibitor of matrix metalloproteinase-2 correlates with activation of matrix metalloproteinase- 2 and predicts poor prognosis in tongue squamous cell carcinoma. Int $\mathrm{J}$ Cancer 95: 44-50, 2001.

17 Van Trappen PO, Ryan A, Carroll M, Lecoeur C, Goff L, Gyselman VG, Young BD, Lowe DG, Pepper MS, Shepherd JH and Jacobs IJ: A model for co-expression pattern analysis of genes implicated in angiogenesis and tumour cell invasion in cervical cancer. Br J Cancer 87: 537-544, 2002.

18 Chan-Hui PY and Weaver R: Human mitogen-activated protein kinase kinase kinase mediates the stress-induced activation of mitogen-activated protein kinase cascades. Biochem J 336(Pt 3): 599-609, 1998.

19 Silbergeld DL and Chicoine MR: Isolation and characterization of human malignant glioma cells from histologically normal brain. J Neurosurg 86: 525-531, 1997.

20 Siviero A, Gallo E, Maggini V, Gori L, Mugelli A, Firenzuoli F and Vannacci A: Curcumin, a golden spice with a low bioavailability. J Herbal Med 5: 57-70, 2015.

21 Mahmood K, Zia KM, Zuber M, Salman M and Anjum MN: Recent developments in curcumin and curcumin based polymeric materials for biomedical applications: A review. Int $\mathrm{J}$ Biol Macromol 81: 877-890, 2015.

22 Paramasivam M, Poi R, Banerjee $\mathrm{H}$ and Bandyopadhyay A: High-performance thin layer chromatographic method for quantitative determination of curcuminoids in Curcuma longa germplasm. Food Chem 113: 640-644, 2009.

23 Yang H, Fan S, An Y, Wang X, Pan Y, Xiaokaiti Y, Duan J, Li $\mathrm{X}$, Tie L, Ye M and Li X: Bisdemethoxycurcumin exerts proapoptotic effects in human pancreatic adenocarcinoma cells through mitochondrial dysfunction and a GRP78-dependent pathway. Oncotarget 7: 83641-83656, 2016.

24 Hsieh WT, Lin HY, Chen JH, Lin WC, Kuo YH, Wood WG, Lu $\mathrm{HF}$ and Chung JG: Latex of Euphorbia antiquorum-induced Sphase arrest via active ATM kinase and MAPK pathways in human cervical cancer HeLa cells. Environ Toxicol 30: 1205$1215,2015$.

25 Ji BC, Hsiao YP, Tsai CH, Chang SJ, Hsu SC, Liu HC, Huang YP, Lien JC and Chung JG: Cantharidin impairs cell migration and invasion of A375.S2 human melanoma cells by suppressing MMP-2 and -9 through PI3K/NF-kappaB signaling pathways. Anticancer Res 35: 729-738, 2015.

26 Huang YP and Chang NW: PPARalpha modulates gene expression profiles of mitochondrial energy metabolism in oral tumorigenesis. BioMedicine 6: 3, 2016.

27 Lin MC, Tsai SY, Wang FY, Liu FH, Syu JN and Tang FY: Leptin induces cell invasion and the upregulation of matrilysin in human colon cancer cells. BioMedicine 3: 174-180, 2013. 
28 Chan CY, Lien CH, Lee MF and Huang CY: Quercetin suppresses cellular migration and invasion in human head and neck squamous cell carcinoma (HNSCC). BioMedicine 6: 15, 2016.

29 Lin YJ, Ho TJ, Lin TH, Hsu WY, Huang SM, Liao CC, Lai CH, Liu X, Tsang H, Lai CC and Tsai FJ: P-coumaric acid regulates exon 12 splicing of the ATP7B gene by modulating hnRNP A1 protein expressions. BioMedicine 5: 1-9, 2015.

$30 \mathrm{Wu}$ SH, Hsiao YT, Kuo CL, Yu FS, Hsu SC, Wu PP, Chen JC, Hsia TC, Liu HC, Hsu WH and Chung JG: Bufalin inhibits NCIH460 human lung cancer cell metastasis in vitro by inhibiting MAPKs, MMPs, and NF-kappaB pathways. Am J Chin Med 43: 1247-1264, 2015.

31 Huang YL, Chu YL, Ho CT, Chung JG, Lai CI, Su YC, Kuo YH and Sheen LY: Antcin K, an active triterpenoid from the fruiting bodies of basswood-cultivated Antrodia cinnamomea, inhibits metastasis via suppression of integrin-mediated adhesion, migration, and invasion in human hepatoma cells. J Agric Food Chem 63: 4561-4569, 2015.

32 Chu SC, Yu CC, Hsu LS, Chen KS, Su MY and Chen PN: Berberine reverses epithelial-to-mesenchymal transition and inhibits metastasis and tumor-induced angiogenesis in human cervical cancer cells. Mol Pharmacol 86: 609-623, 2014.

33 Kessler SA, Shimosato-Asano H, Keinath NF, Wuest SE, Ingram $\mathrm{G}$, Panstruga $\mathrm{R}$ and Grossniklaus U: Conserved molecular components for pollen tube reception and fungal invasion. Science 330: 968-971, 2010.

34 Amalraj A, Pius A, Gopi S and Gopi S: Biological activities of curcuminoids, other biomolecules from turmeric and their derivatives - A review. J Tradit Complement Med 7: 205-233, 2017.

35 Chen HW, Lee JY, Huang JY, Wang CC, Chen WJ, Su SF, Huang CW, Ho CC, Chen JJ, Tsai MF, Yu SL and Yang PC: Curcumin inhibits lung cancer cell invasion and metastasis through the tumor suppressor HLJ1. Cancer Res 68: 7428-7438, 2008.

36 Lin SS, Lai KC, Hsu SC, Yang JS, Kuo CL, Lin JP, Ma YS, Wu $\mathrm{CC}$ and Chung JG: Curcumin inhibits the migration and invasion of human A549 lung cancer cells through the inhibition of matrix metalloproteinase-2 and -9 and vascular endothelial growth factor (VEGF). Cancer Lett 285: 127-133, 2009.

37 Yodkeeree S, Ampasavate C, Sung B, Aggarwal BB and Limtrakul P: Demethoxycurcumin suppresses migration and invasion of MDA-MB-231 human breast cancer cell line. Eur J Pharmacol 627: 8-15, 2010.

38 Yodkeeree S, Chaiwangyen W, Garbisa S and Limtrakul P: Curcumin, demethoxycurcumin and bisdemethoxycurcumin differentially inhibit cancer cell invasion through the downregulation of MMPs and uPA. J Nutr Biochem 20: 87-95, 2009.

39 Park SJ, Kong HK, Kim YS, Lee YS and Park JH: Inhibition of S-adenosylhomocysteine hydrolase decreases cell mobility and cell proliferation through cell cycle arrest. Am J Cancer Res 5: 2127-2138, 2015

40 Wu ZY, Lien JC, Huang YP, Liao CL, Lin JJ, Fan MJ, Ko YC, Hsiao YP, Lu HF and Chung JG: Casticin inhibits A375.S2 human melanoma cell migration/invasion through downregulating NF-kappaB and matrix metalloproteinase-2 and -1. Molecules 21: 384, 2016.

41 Liao CL, Lai KC, Huang AC, Yang JS, Lin JJ, Wu SH, Gibson Wood W, Lin JG and Chung JG: Gallic acid inhibits migration and invasion in human osteosarcoma U-2 OS cells through suppressing the matrix metalloproteinase-2/-9, protein kinase B (PKB) and PKC signaling pathways. Food Chem Toxicol 50: 1734-1740, 2012
42 Nair S, Phillips AO, Norton N, Spurlock G, Williams HJ, Craig KJ, Williams JD, Williams NM and Bowen T: Further evidence for the association of MMP9 with nephropathy in type 2 diabetes and application of DNA pooling technology to candidate gene screening. J Nephrol 21: 400-405, 2008.

43 Bauvois B: New facets of matrix metalloproteinases MMP-2 and MMP-9 as cell surface transducers: outside-in signaling and relationship to tumor progression. Biochim Biophys Acta 1825: 29-36, 2012.

44 Matsumura T, Sugimachi K, Takahashi Y, Uchi R, Sawada G, Ueda M, Hirata H, Sakimura S, Ueo H, Takano Y, Kurashige J, Shinden Y, Eguchi H, Sudo T, Yamamoto H, Doki Y, Mori M and Mimori K: Clinical significance of GAB2, a scaffolding/docking protein acting downstream of EGFR in human colorectal cancer. Ann Surg Oncol 21(Suppl 4): S743-749, 2014.

45 Martinelle N, Holst M, Soder O and Svechnikov K: Extracellular signal-regulated kinases are involved in the acute activation of steroidogenesis in immature rat Leydig cells by human chorionic gonadotropin. Endocrinology 145: 4629-4634, 2004.

46 Tsai EM, Chan TF, Chen YH, Hsu SC, Chuang CY and Lee JN: Mifepristone attenuates human chorionic gonadotropin-induced extracellular signal-regulated kinase $1 / 2$ phosphorylation, cyclooxygenase-2, and prostaglandin E2 production in human granulosa luteal cells. Fertil Steril 89: 1522-1529, 2008.

47 Babykutty S, Suboj P, Srinivas P, Nair AS, Chandramohan K and Gopala S: Insidious role of nitric oxide in migration/invasion of colon cancer cells by upregulating MMP-2/9 via activation of cGMP-PKG-ERK signaling pathways. Clin Exp Metastasis 29: 471-492, 2012.

48 Tan CT, Chu CY, Lu YC, Chang CC, Lin BR, Wu HH, Liu HL, Cha ST, Prakash E, Ko JY and Kuo ML: CXCL12/CXCR4 promotes laryngeal and hypopharyngeal squamous cell carcinoma metastasis through MMP-13-dependent invasion via the ERK1/2/AP-1 pathway. Carcinogenesis 29: 1519-1527, 2008.

49 Fong Y, Wu CY, Chang KF, Chen BH, Chou WJ, Tseng $\mathrm{CH}$, Chen YC, Wang HD, Chen YL and Chiu CC: Dual roles of extracellular signal-regulated kinase (ERK) in quinoline compound BPIQ-induced apoptosis and anti-migration of human non-small cell lung cancer cells. Cancer Cell Int 17: 37, 2017.

50 Zeisberg $\mathrm{M}$ and Neilson EG: Biomarkers for epithelialmesenchymal transitions. J Clin Invest 119: 1429-1437, 2009.

51 Iwatsuki M, Mimori K, Yokobori T, Ishi H, Beppu T, Nakamori S, Baba $\mathrm{H}$ and Mori $\mathrm{M}$ : Epithelial-mesenchymal transition in cancer development and its clinical significance. Cancer Sci 101: 293-299, 2010.

52 Gonzalez DM and Medici D: Signaling mechanisms of the epithelial-mesenchymal transition. Sci Signal 7: re8, 2014.

53 Kalluri R and Weinberg RA: The basics of epithelialmesenchymal transition. J Clin Invest 119: 1420-1428, 2009.

54 Tam WL and Weinberg RA: The epigenetics of epithelialmesenchymal plasticity in cancer. Nat Med 19: 1438-1449, 2013.

55 Guttridge DC, Albanese C, Reuther JY, Pestell RG and Baldwin AS Jr.: NF-kappaB controls cell growth and differentiation through transcriptional regulation of cyclin D1. Mol Cell Biol 19: 5785-5799, 1999.

56 Yamamoto Y and Gaynor RB: Therapeutic potential of inhibition of the NF-kappaB pathway in the treatment of inflammation and cancer. J Clin Invest 107: 135-142, 2001.

Received April 20, 2018

Revised May 18, 2018

Accepted May 21, 2018 